\title{
CORPORATE CULTURE AND PARTICIPATION: INDEPENDENT CONSTRUCTS?
}

\author{
A Odendaal \\ Department of Human Resource Management \\ Technikon SA, Roodepoort \\ G Roodt \\ Department of Human Resource Management \\ Rand Afrikaans University
}

\begin{abstract}
OPSOMMING
Die doel van hierdie studie is om te bepaal of deelnemende bestuur en korporatiewe kultuur onderling uitsluitende (onafhanklike) konsepte is. Die Raad vir Geesteswetenskaplike Navorsing (RGN) het 'n kultuur- en klimaatvraelys op 'n steekproef van 2357 respondente, vanuit 'n populasie van 23564 persone wat werksaam is in 'n para-militêre instansie, toegepas. Die datastel van die RGN is vir die doel van hierdie studie gebruik. 'n Paneel deskundiges het dimensies wat op deelname betrekking het geïdentifiseer aan die hand van voorafbepaalde kriteria en die oorblywende items was op kultuur van toepassing. Die resultate van die faktor- en itemontledings het bevind dat deelnemende bestuur en korporatiewe kultuur, soos bestudeer vanuit die persepsies van werknemers en bestuur, oorwegend 'n gemeenskaplike eienskap meet en nie onafhanklike konstrukte is soos wel gekonseptualiseer deur deskundiges nie.
\end{abstract}

\section{ABSTRACT}

The objective of this study was to determine whether participative management and corporate culture are mutually exclusive (independent) concepts. The Human Sciences Research Council (HSRC) used an organisational climate and culture questionnaire and applied it to the test sample of 2357 personnel from a population of 23564 people working for a paramilitary organisation. The data set of the HSRC was used for the purpose of this study. A panel of experts identified the items in the questionnaire which related to participation according to predetermined criteria and the remaining items were applicable to corporate culture. The results of the factor and item analyses indicate that participative management and corporate culture, as perceived by workers and management, were interrelated and were not independent concepts as conceptualised by the experts.

South African companies are experiencing major changes at the moment, and one of the goals of these changes is to create a more representative work-force. Another goal is to develop a more inclusive management style. This may enhance the quality of work-life and psycho-social well-being in most South African companies.

Participative management is a growing trend worldwide and is especially in South Africa driven by the spirit of democracy. The ANC's Reconstruction and Development Programme (1995) states clearly that "legislation must facilitate worker participation and decision-making in the world of work." Myburgh (1990) indicated that there is support in South Africa for the underlining principle that the workforce must have a greater say in their working conditions and in the operational aspects that influence them directly. The question arises to what extend and in which manner this say need to be addressed in an organisation.

In this regard Loubser (1988) observed that management has two choices, to allow conditions in the organisation to determine the role of the workforce, or to acknowledge the role of workers in participative decision-making and actively develop a joint strategy of participation. Consequently Laubscher (1991) identified the need to determine a universally accepted meaning for the term participative management. For the purpose of this study, participative management can operationally be defined as an approach which recognises that organisational decision-making must take place in such a way that the input and responsibility be extended to the lowest level as applicable to the decision being taken. The aim is thus to ensure that effective decisions are taken by the right person. Empowerment is the authority to make decisions within one's area of work without having to get approval from anyone else, where involvement can be seen as the mechanism to ensure sufficient inputs in the decision-making process.

The dominant theme in contemporary South Africa, according to Roodt (1997), is empowerment. The unprecedented transfer and transformation of political power is reshaping the economic power relationships in South Africa. This increasingly manifests itself in the business sector with particular consequences for management. Empowerment affects the way work is done as well as how people relate to each other, but it is important to note that empowerment is a global management phenomenon, not merely a South African political idiosyncrasy.

Although South Africa has moved towards a democratic political dispensation, the establishment of democracy in the workplace still lags behind. It is clear from available literature that worker participation is a trend that has not developed systematically but has been influenced by diverse forms of initiative from different countries. Presently organisations pursue change under many auspices. Some seek to improve strategy, vision, or values. Others recognise that a "business-asusual" attitude can suppress innovation and competitiveness and therefore have instituted workteams, total quality management programs, employee involvement, re-engineering, diversity and learning organisation interventions (Loubser, 1988, McLagan \& Nel, 1995, Pretorius, 1995; Weeks, 1995). Unfortunately, many of these programs have been unsuccessful in both the public and private sectors, leading to the general confusion in the discussion of worker participation in South Africa (Coye \& Belohlav, 1995; Laubscher, 1991; Yukl, 1981).

In order to be successful, these programs must be incorporated into a general movement toward participative management. There are however several reasons why the move towards participation in South Africa is accelerating:

Information is increasingly available and people can now manage their own activities and participate with minimal interference and direction from management. Globalisation is another driving force towards participation. People, organisations and even nations, that in the past were relatively isolated, now find themselves face to face via fax, television, internet and cellular phone. As technology transforms labour, participation receives another boost since technology is changing the nature 
of work thereby freeing up time that can be devoted to participation (McLagan \& Nel, Pretorius, 1995; Vroom \& Jago, 1988; Weeks, 1995).

But the kind of fundamental change that dramatically increases quality, productivity and customer retention remains elusive and short-term. In spite of all this, the move toward participation continues to gain momentum. Research by Allen \& Dyer (1990); Desatnick (1986); McLagan \& Nel (1995); Miller (1991); Prentice (1990); Preston (1989) and Vroom \& Jago, (1988) have found that the move towards participation requires a broad and fundamental change in the generic code of organisations.

In the aforementioned literature the assumption is made that the style of managing work relationships is conditioned by the culture of the organisation. On this basis an effective management style will be the most powerful instrument at the disposal of management to steer South Africa away from the present abyss of industrial conflict and low productivity, towards an empowered and involved workforce. It is therefore important for top management to be aware of their oganisational culture and the manner in which it is reflected in their chosen management style (Anstey, 1990; Bellingham, Cohen, Edwards \& Allen, 1990; Kilbourne, 1991; Mitchell \& Tucker, 1992; Prentice, 1990; Pretorius, 1995).

Coetzee (1988) found that traditionally and culturally the management style in South Africa was autocratic. As the social norms change and attitudes become more open it was observed that the autocratic management style became demotivational and caused the destruction of informal communication channels. Esterhuyse (1994) and Mboweni (1994) are of the opinion that the transformation of the civil service will be high on the agenda for the next five years. This study was consequently undertaken in a paramilitary organisation that, with time and accordingly to cultural values, learned to used an autocratic management style.

With no theoretical foundation for the integrated study of the dimensions of participation and corporate culture, the need was identified to study the relationship between participative management and corporate culture. The development of an industrial psychological approach to the problem will be of great value for the successful implementation of participative management in South Africa. It is against this background that this study aims to determine whether corporate culture and participative management are mutually exclusive (independent) concepts.

However, before the nature of the relationship between the variables can be determined, the dimensions of participation and corporate culture had to be studied in a systematic manner. The management of these dimensions is an indispensable prerequisite for the successful implementation of participative measures.

A review of the literature on participative management (Odendaal, 1997) reveals that the involvement and empowerment of employees are important dimensions of participation. From a cultural perspective, it can be concluded that corporate culture is one of the organisational processes that is based on established values and norms which direct employee behaviour, attitudes, perceptions and decisions.

Based on the predetermined need for further study on participative management and corporate culture, a preceding aim of this study was to determine theoretical guidelines for identifying dimensions of participation in order to develop a questionnaire on participation. The main objective was to determine by means of an empirical study whether participative management and corporate culture, as identified by experts, were mutually exclusive (independent) concepts.

From the abovementioned problem statement the following research hypothesis was formulated for the empirical study:

Participative management and corporate culture, as conceptualised by subject experts, can be perceived as independent concepts.

\section{METHOD}

The method of research used in this study will subsequently be discussed:

TABLE 1

THEORETICAL DIMENSIONS OF PARTICIPATION

\begin{tabular}{lll}
\hline DIMENSION & AUTHOR & NUMBER \\
& OF ITEMS
\end{tabular}

\begin{tabular}{|c|c|c|c|}
\hline 1. & Communication & $\begin{array}{l}\text { Coetzee, 1988; Laubscher, 1991; Prentice, 1990; } \\
\text { Weeks, } 1995 .\end{array}$ & 8 \\
\hline 2. & Teamwork & $\begin{array}{l}\text { Kilbourne, 1991; Laubscher, 1991; Madima, } \\
\text { 1995; Thomson, } 1993 .\end{array}$ & 6 \\
\hline 3. & Shared vision & $\begin{array}{l}\text { Kilbourne, 1991; Laubscher, 1991; Pretorius, } \\
1995 .\end{array}$ & 4 \\
\hline 4. & Worker involvement & Kilbourne, 1991; Madima, 1995; Weeks, 1995. & 4 \\
\hline 5. & Joint objectives & Coetzee, 1988; Macher,1991; Prentice, 1990. & 4 \\
\hline 6. & Equality & Madima, 1995; Pretorius, 1995. & 6 \\
\hline 7. & Joint workvalues: & Madima, 1995. & 4 \\
\hline & * Trust & Laubscher, 1991; Macher, 1991; Nel, 1990. & \\
\hline & ${ }^{*}$ Proud of work & Kilbourne, 1991; Macher, 1991. & \\
\hline & * Respect & Pretorius, 1995. & \\
\hline & ${ }^{*}$ Honesty & Kilbourne, 1991. & \\
\hline & * Loyalty & $\begin{array}{l}\text { Kilbourne, 1991; Macher, 1991; Thomson, } \\
1993 .\end{array}$ & \\
\hline 8. & Control over work & Laubscher, 1991. & 3 \\
\hline 9. & Transparency & Weeks, 1995. & 5 \\
\hline 10. & Joint decision-making & Madima, 1995. & 4 \\
\hline
\end{tabular}




\section{Sample}

A stratified random sample of $2357(\mathrm{~N}=2357)$ was drawn from a population of 23564 people working for a parastatal organisation. From the total population 1907 questionnaires were returned, representing a response rate of $80,9 \%$. After the deduction of questionnaires with missing values, 1818 questionnaires were used in the final statistical analysis.

The majority of the respondents were in the age group 26 to 31 . Of these respondents $63,88 \%$ were male and $36,12 \%$ female. The qualifications of the respondents were relatively high with 51,63\% having standard 10 and 19,03\% having a higher diploma or degree and 5,82\% with post graduate qualifications. From the total sample just $23,52 \%$ had a qualification lower than standard 10.

The participants occupied job levels ranging from operation to top-management with a relative even distribution across the first 10 years of service.

\section{Measuring instruments}

In the empirical part of this study a corporate climate and culture questionnaire of the Human Sciences Research Council (HSRC) consisting of 150 items was used. The questionnaire was developed by the HSRC on instruction by the organisation and covered both participative and culture concepts. In consultation with the authors, a panel of experts was asked to identify the items in the questionnaire which related to participation according to predetermined criteria (refer to table 1) and the remaining items were applicable to corporate climate and culture (table 2)

A summary of the dimensions of participation as identified by different authors is reported in Table 1 . The research indicates that these dimensions can be seen as theoretical guidelines for participation.

The corporate climate and culture dimensions were identified by management and reflects the core characteristics of the corporate culture environment of the specific parastatal organisation. The dimensions were based on the operational realities facing employees in their daily work.

\section{Participation Questionnaire}

In identifying dimensions of participation the following procedure was followed by the panel of experts:

- Based on a literature study, ten dimensions of participation were identified and assessed by the panel of experts (Refer to Table 1).

- The majority vote was used to place a specific item within the identified dimensions.

- The participation questionnaire consists of 48 items in total.

\section{Corporate climate and culture questionnaire}

For the purpose of this study the culture questionnaire consists of the remaining 99 items (excluding 3 organisation specific questions). The 13 dimensions covered by the questionnaire were identified by the specific organisation and reported in Table 2.

\section{Procedure}

For the purpose of this particular study an existing data set of the HSRC of the "Climate and Culture Questionnaire" was used. In the HSRC study respondents were asked to rate each of the 150 items in the questionnaire on a five point Likert type scale ranging from "agree completely" to "disagree completely". Research by the HSRC (1994) has demonstrated that an average of 3,200 can be seen as a reasonable cut off point to differentiate between positive and negative perceptions.

\section{Statistical analysis}

Descriptive statistics are available on request but due to the magnitude all statistical calculations can not be reported in this article. The empirical objective of the study was to determine whether participation and corporate culture are independent concepts and therefore factor analysis as statistical technique was employed. According to Kim and Meuller (1978), the aim of a factor analysis is to reduce a relatively large number of observed variables to a small number of hypothetical constructs. For analysis purposes the BMDP 4M computer program was employed by the Statistical Consultation Service of the Rand Afrikaans University, to conduct a first and second order factor analysis.

\section{RESULTS}

According to the criteria set by Kaiser (1961) the eigen values of the intercorrelation matrix $(147 \times 147)$ were calculated and 32 factors with an eigen value greater than one were postulated. The intercorrelation matrix was submitted to a principle factor analysis (PFA) and then rotated to a simple structure by means of a varimax rotation. Subsequently all items with a high negative load were reflected and items with a high loading on a specific factor were grouped together. These subtest scores

TABLE 2

DIMENSIONS OF CORPORATE CLIMATE AND CULTURE QUESTIONNAIRE

\begin{tabular}{lll}
\hline DIMENSION & CONTENT & NUMBER \\
& OF ITEMS
\end{tabular}

1. General effectiveness

2. Cost effectiveness

3. Management

4. Work environment

5. Social involvement

6. Reward and discipline

7. Authority

8. Training and development

9. Industrial Relations

10. Transfers

11. Job satisfaction

12. Transformation

13. Fringe benefits
Perfection of company objectives.

Economical use of money, time and equipment.

Leading, contolling, participative management.

Perception of work environment.

Perception of trust with regard to colleaques.

Consistency, discipline, recognition and rewards

Interpersonal relations and authority.

Perceptions with regard to training, development and performance appraisals.

Effectiveness of labour relations and discriminations.

Handling of transfers.

5

Different aspects of job satisfaction. 
were intercorrelated $(24 \times 24$ as reported in Table 3$)$ and according to Kaiser's (1961) criteria five (5) second-order factors were postulated and subjected to an oblique rotation by means of the direct oblimin method. According to Schepers (1992) this procedure is recommended if there is a possibility that the test items are differentially skew. This procedure will prevent the creation of artefactors.
From the results it appears that some factors correlate highly with others and that some were non-determined (two or less loadings on each factor). Therefore the PFA was repeated for a three and two factor solution and two properly defined second-order factors were identified, as presented in Table 5.

TABLE 3

INTERCORRELATION MATRIX OF SIMPLIFIED FACTOR SCORES (SFS) $(24 \times 24)$

SFS 1 SFS 2 SFS 3 SFS 4 SFS 5 SFS 6 SFS 7 SFS 8 SFS 9 SFS 10 SFS 11 SFS 12 SFS 13 SFS 14 SFS 15 SFS 18 SFS 19 SFS 20 SFS 21 SFS 22 SFS 24 SFS 26 SFS 27 SFS 28

SFS $1 \quad 1,0000$

SFS $20,7452 \quad 1,0000$

$\begin{array}{llll}\text { SFS } 3 & 0,2240 & 0,1688 & 1,0000\end{array}$

$\begin{array}{lllll}\text { SFS } 4 & 0,6699 & 0,6292 & 0,1030 & 1,0000\end{array}$

SFS $5 \quad 0,5560 \quad 0,6708 \quad 0,1120 \quad 0,5420 \quad 1.0000$

$\begin{array}{lllllllll}\text { SFS } 6 & 0,0752 & 0,1507 & -0,2200 & 0,1657 & 0,1920 & 1,0000\end{array}$

$\begin{array}{llllllllllll}\text { SFS } 7 & 0,5029 & 0,4724 & 0,0688 & 0,4385 & 0,3540 & 0,1534 & 1,0000\end{array}$

$\begin{array}{lllllllllllllll}\text { SFS } 8 & 0,2881 & 0,1860 & 0,2293 & 0,0978 & 0,1237 & 0,0151 & 0,0435 & 1,0000\end{array}$

$\begin{array}{lllllllllllllll}\text { SFS } & 0,4365 & 0,4120 & 0,0509 & 0,3476 & 0,3076 & 0,0973 & 0,3201 & 0,0632 & 1,0000\end{array}$

$\begin{array}{lllllllllll}\text { SFS } 10 & 0,5820 & 0,4577 & 0,0951 & 0,5100 & 0,3885 & 0,1267 & 0,3621 & 0,1965 & 0,2763 & 1,0000\end{array}$

$\begin{array}{llllllllllllllllllllllll}\text { SFS } 11 & 0,0964 & 0,1089 & 0,1811 & 0,0773 & 0,1121 & -0,1153 & 0,0845 & 0,0671 & 0,0907 & 0,0648 & 1,0000\end{array}$

$\begin{array}{llllllllllllllllll}\text { SFS } 12 & 0,4150 & 0,4808 & 0,0208 & 0,3267 & 0,3705 & 0,1584 & 0,3308 & 0,0987 & 0,3500 & 0,2524 & 0,0681 & 1,0000\end{array}$

$\begin{array}{llllllllllllllll}\text { SFS } 13 & 0,0121 & 0,0491 & 0,4391 & -0,0061 & 0,0351 & -0,0955 & 0,0757 & 0,1020 & 0,0338 & 0,0268 & 0,0528 & -0,0037 & 1,0000\end{array}$

$\begin{array}{lllllllllllllllllllllll}\text { SFS } 14 & 0,1053 & 0,0803 & 0,3822 & 0,0653 & 0,0568 & -0,1717 & 0,0607 & -0,0190 & 0,0426 & 0,0734 & 0,1152 & -0,0265 & 0,2033 & 1,0000\end{array}$

$\begin{array}{llllllllllllllll}\text { SFS } 15 & 0,0610 & 0,4697 & 0,0759 & 0,4331 & 0,3732 & 0,0819 & 0,3411 & 0,0710 & 0,2835 & 0,3481 & 0,0697 & 0,2508 & 0,0336 & 0,0357 & 1,0000\end{array}$

$\begin{array}{lllllllllllllllllllllllll}\text { SFS } 18 & 0,3202 & 0,2117 & -0,0025 & 0,1724 & 0,1796 & 0,0187 & 0,1512 & 0,2047 & 0,1540 & 0,1870 & -0,0185 & 0,2804 & -0,0646 & -0,0511 & 0,1276 & 1,0000\end{array}$

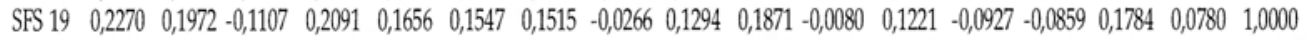

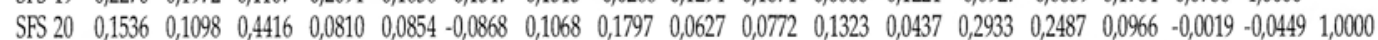

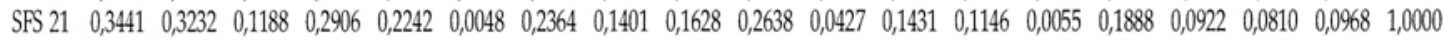

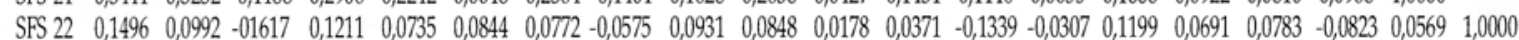

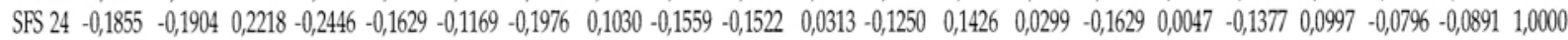

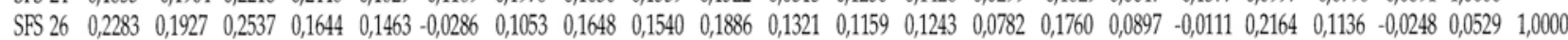

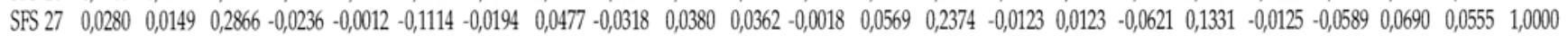

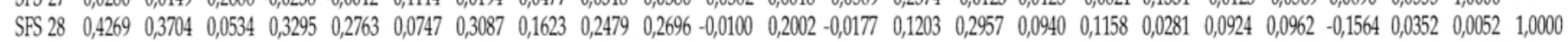

The reliability index of the items with a loading on a specific factor was determined by means of the NP-50 item-analysis program. The following results were obtained in the study.

The second-order PFA identified five factors with an eigenvalue greater than one, as presented in Table 4.

TABLE 4

EIGENVALUES OF POSTULATED SECOND-ORDER FACTORS

\begin{tabular}{cc}
\hline FACTOR & EIGENVALUE \\
\hline $\mathbf{1}$ & $\mathbf{5 , 4 2 0 1 2}$ \\
$\mathbf{2}$ & $\mathbf{2 , 5 8 7 6 7}$ \\
$\mathbf{3}$ & $\mathbf{1 , 2 8 4 8 8}$ \\
$\mathbf{4}$ & $\mathbf{1 , 1 1 8 1 1}$ \\
$\mathbf{5}$ & $\mathbf{1 , 0 4 8 3 9}$ \\
6 & 0,999112 \\
7 & 0,924898 \\
8 & 0,917943 \\
9 & 0,894923 \\
10 & 0,856137 \\
11 & 0,833959 \\
12 & 0,789320 \\
13 & 0,733677 \\
14 & 0,698993 \\
15 & 0,678986 \\
18 & 0,657133 \\
19 & 0,619583 \\
20 & 0,586063 \\
21 & 0,551626 \\
24 & 0,512897 \\
26 & 0,439131 \\
27 & 0,376730 \\
28 & 0,288109 \\
\hline
\end{tabular}

The next step was to determine the reliability of each factor by means of an item analysis (NP50-programme). The item analysis of the 100 items in Scale I rejected items 47, 56, 68 and 141 after four iterations. The statistics with regard to the remaining 96 items are reported in Table 6 . The results show acceptable levels of reliability that fluctuate between 0,813 and 0,313 . The item-test correlations vary from 0,257 to 0,692 and the standard deviation of the items from 0,957 to 1,989 . The 96 items of Scale I have an internal consistency coefficient (Cronbach Alpha) of 0,976.

The content of Scale I refers to the dimension of quality of work and the effectiveness of management, communication, social involvement, teamwork and recognition. Jointly this factor can possibly refer to involvement.

The item analysis of the 33 items of Scale II rejected items 37, 73 and 91 after three iterations. The statistics of the remaining 30 items are reported in Table 7 . The levels of reliability fluctuate between 0,674 and 0,348 and the itemtest correlation from 0,300 to 0,511 . The standard deviation of the items varied from 1,013 to 1,478. The internal consistency coefficient (Cronbach Alpha) of the 30 items of Scale II is 0,843 .

The content of Scale II refers to general working conditions and power sharing, training, development, working hours and fringe benefits which can possibly refer to empowerment.

The results of the factor analysis indicate that the items identified by the experts were randomly scattered across the two obtained factors and there is no statistical evidence for the hypothesis that "culture" and "participation" are independent concepts. The intercorrelation coefficient of Scale I and Scale II is 0,7452 as reported in Table 8 , and these scales share a common variance of about $50 \%$. 
TABLE 5

SFS 1 Items 101, 128, 121, 116, 112, 105, 66, 111, 115, 86, 61, 113, 102, 104, $96,124,106,148,100,134,85,117,79,119,93,32,72,88,98,143,45$, $92,62,41,60,97,24,125,84,90,70,135,29,49,140,107,52,144,31$, $69,149,38,127,78,109,83,138,64,39,19,122,129,28,136,42$

SFS 2: $\quad$ Items $6,9,5,11,10,20,14,21,15,8$

SFS 4 : Items $54,57,50,53,76,74$

SFS 5: Items 1, 2, 16, 3

SFS 10: Item 94

SFS 7: Items 43,36

SFS 15: Items 58,131

SFS 12: Items $7,13,4,18$

SFS 9 Items 22,87

SFS 3: Items $67,133,123,34,71,63,89,120,25,110,146,108,126,137,80$, $65,99,91,95,48,130,55,103$

SFS 20: Items 118, 46

SFS 13: Items 114, 145, 77

SFS 14: Items 40, 59, 44, 12

SFS 26: Items 73, 37, 82

SFS 27: Item 51

SFS 6: Items 150, 147, 35, 30

SFS 24: Items 139, 47

SFS 8: Items 142, 17

SFS 11: Items 23, 27

SFS 22: Items 68, 141

SFS 19: Items 56, 75

SFS 21: Item 132

SFS 18: Items 81,26

SFS 28: Item 33

Total items per factor

\begin{tabular}{|c|c|c|}
\hline 65 & 0,883 & 0,147 \\
\hline 10 & 0,834 & 0,092 \\
\hline 6 & 0,753 & 0,009 \\
\hline 4 & 0,671 & 0,043 \\
\hline 1 & 0,607 & 0,066 \\
\hline 2 & 0,583 & 0,024 \\
\hline 2 & 0,574 & 0,035 \\
\hline 4 & 0,512 & $-0,028$ \\
\hline 2 & 0,501 & 0,013 \\
\hline 23 & 0,067 & 0,861 \\
\hline 2 & 0,086 & 0,523 \\
\hline 3 & $-0,012$ & 0,496 \\
\hline 4 & 0,036 & 0,422 \\
\hline 3 & 0,208 & 0,314 \\
\hline 1 & $-0,032$ & 0,297 \\
\hline 4 & 0,220 & $-0,285$ \\
\hline 2 & $-0,283$ & 0,272 \\
\hline 2 & 0,195 & 0,242 \\
\hline 2 & 0,094 & 0,209 \\
\hline 2 & 0,170 & $-0,194$ \\
\hline 2 & 0,284 & $-0,188$ \\
\hline 1 & 0,352 & 0,111 \\
\hline 2 & 0,292 & 0,017 \\
\hline 1 & 0,450 & 0,007 \\
\hline 150 & 100 & 33 \\
\hline
\end{tabular}

\section{DISCUSSION}

From the empirical study it was found that there is no basis for distinction between participation and culture concepts, as postulated by the panel of experts. Although participation can be defined theoretically it still remains an inseparable part of corporate culture. The results of the factor and item analyses indicate that participative management and corporate culture, as perceived by workers and management, are interrelated and are not independent concepts as conceptualised by the experts. This can possibly be attributed to response naivety that according to Morrow, Eastman and McElroy (1991) refers to the inability of respondents to empirically discriminate between what researchers see as a logical distinction between different concepts.

The results of this study support the research of Anstey (1990); Bellingham, Cohen, Edwards and Allen (1990); Kilbourne (1991); Mitchell and Tucker (1992); Prentice (1990) and Pretorius (1995) that culture is an important factor which determines the success or failure of participation. It further supports the results of research conducted by Miller (1991) that a corporate culture supportive of participation should form the basis of any participative measures in an organisation.

The results of this study thus support the literature that a participative culture can only be achieved if all stakeholders are actively involved in an organisation where employee involvement and empowerment are key factors. This implies that participative measures can only be successfully implemented if they are supported by a participative corporate culture.
This study can be used as a point of departure for further research on participative corporate culture. There are, however, certain limitations which must be kept in mind when generalising and interpreting the findings of this study. Firstly the dimensions of participation were identified by means of a subjective rating by a panel of experts. To be objective, a statistical procedure can be used to identify the inter rater reliabilities of items between experts. This method can deliver a more statistically reliable result than the consensus method employed in this study. Secondly, it should be taken into account that the organisational climate and culture questionnaire was developed for a specific organisation and that the transferability of the concepts to another culture will not necessarily produce the same metric properties.

The findings of this study indicate that there are certain practical applications for a participative corporate culture in a new South Africa which has experienced many political and economic transformations during the last four years. The development of a South African instrument to measure participative culture is a priority and challenge for future research.

To enhance the quality of work-life and psycho-social wellbeing in most South African companies, the findings of this study indicate that the participation focus would have to integrate the principles of empowerment and involvement into articulated corporate values. These corporate values should be operationalised through visible management processes. 
TABLE 6

ITEM STATISTICS WITH REGARD TO SCALE I

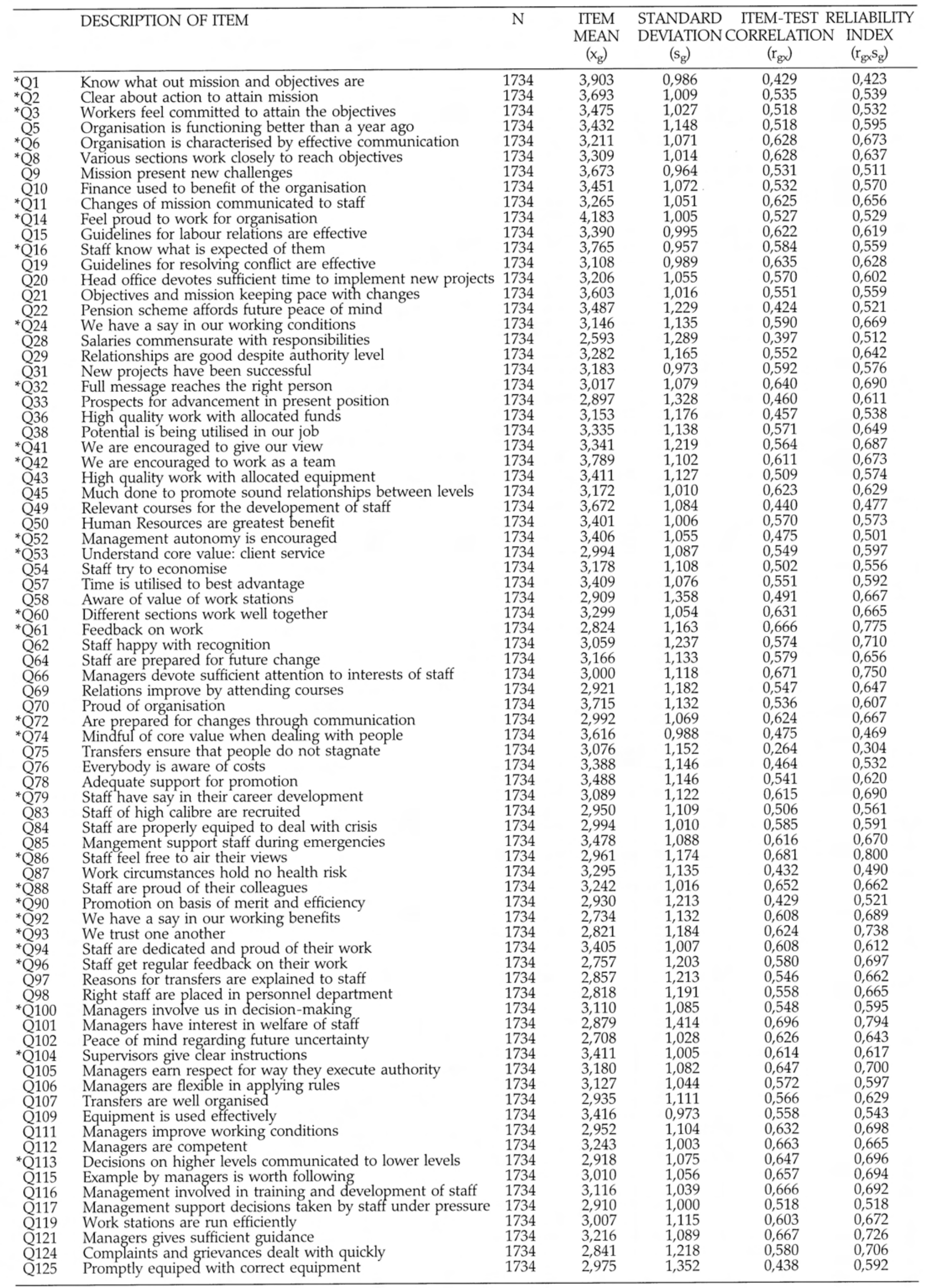


TABLE 6 continued

ITEM STATISTICS WITH REGARD TO SCALE I

\begin{tabular}{|c|c|c|c|c|c|c|}
\hline & DESCRIPTION OF ITEM & $\mathrm{N}$ & $\begin{array}{l}\text { ITEM } \\
\text { MEAN } \\
\left(\mathrm{x}_{\mathrm{g}}\right)\end{array}$ & $\begin{array}{l}\text { STANDARD } \\
\text { DEVIATION C } \\
\qquad\left(\mathrm{s}_{\mathrm{g}}\right)\end{array}$ & $\begin{array}{l}\text { ITEM-TEST RE } \\
\text { ORRELATION } \\
\left(\mathrm{R}_{\mathrm{g} x}\right)\end{array}$ & $\begin{array}{l}\text { ELIABILITY } \\
\text { INDEX } \\
\left(\mathrm{r}_{\mathrm{gx}} \mathrm{s}_{\mathrm{g}}\right)\end{array}$ \\
\hline Q122 & Conduct of supervisors is unapproachable & 1734 & 2,985 & 1,062 & 0,341 & 0,362 \\
\hline *Q127 & Adequate information from other departments & 1734 & 2,824 & 1,022 & 0,552 & 0,564 \\
\hline Q128 & Receive recognition for good work & 1734 & 2,693 & 1,175 & 0,694 & 0,816 \\
\hline Q129 & Office accommodation is acceptable & 1734 & 2,955 & 1,224 & 0,461 & 0,565 \\
\hline *Q131 & Suggestions by work groups promote communication & 1734 & 2,990 & 1,101 & 0,564 & 0,621 \\
\hline *Q̄132 & Everyone understands the language we use & 1734 & 3,510 & 1,229 & 0,373 & 0,459 \\
\hline Q134 & Feel like one big family & 1734 & 2,779 & 1,227 & 0,656 & 0,805 \\
\hline Q135 & Know what to do during emergency & 1734 & 3,374 & 1,550 & 0,556 & 0,639 \\
\hline Q136 & Comfortable in working environment & 1734 & 3,431 & 1,104 & 0,589 & 0,650 \\
\hline Q138 & Attention is given to personal circumstances in transfers & 1734 & 2,864 & 1,146 & 0,557 & 0,638 \\
\hline \#Q139 & Neatness is overemphasised at expense of productivity & 1734 & 2,931 & 1,187 & 0,251 & 0,298 \\
\hline Q140 & Smokers accommodate non-smokers & 1734 & 2,651 & 1,345 & 0,304 & 0,409 \\
\hline *Q143 & Rely on one another's help & 1734 & 3,356 & 1,083 & 0,604 & 0,654 \\
\hline \#Q144 & Recruitment procedure are thorough & 1734 & 2,974 & 1,113 & 0,539 & 0,600 \\
\hline Q148 & Policy is applied reasonably and fairly & 1734 & 3,222 & 1,027 & 0,672 & 0,691 \\
\hline Q149 & Feel safe in work environment & 1734 & 3,225 & 1,163 & 0,557 & 0,648 \\
\hline
\end{tabular}

\#Items reflected

*Participation items

Cronbach Alpha = 0,976

Total items $=96$

TABLE 7

ITEM STATISTICS WITH REGARD TO SCALE II

\begin{tabular}{|c|c|c|c|c|c|c|}
\hline & DESCRIPTION OF ITEM & $\mathrm{N}$ & $\begin{array}{l}\text { ITEM } \\
\text { MEAN } \\
\left(x_{\mathrm{g}}\right)\end{array}$ & $\begin{array}{l}\text { STANDARD } \\
\text { DEVIATION } \\
\left(\mathrm{s}_{\mathrm{g}}\right)\end{array}$ & $\begin{array}{l}\text { ITEM-TEST RP } \\
\text { CORRELATION } \\
\left(\mathrm{R}_{\mathrm{g} x}\right)\end{array}$ & $\begin{array}{l}\text { ELIABILITY } \\
\text { INDEX } \\
\left(\mathrm{r}_{\mathrm{gx}} \mathrm{s}_{\mathrm{g}}\right)\end{array}$ \\
\hline Q23 & Professionals can do work better without uniforms & 1734 & 3,001 & 1,478 & 0,304 & 0,449 \\
\hline \#Q25 & Military discipline is not important & 1734 & 3,356 & 1,255 & 0,341 & 0,428 \\
\hline Q27 & Professionals do not want to wear uniforms & 1734 & 3,054 & 1,379 & 0,309 & 0,426 \\
\hline${ }^{*} \mathrm{Q} 34$ & Staff further their own interests & 1734 & 2,874 & 1,094 & 0,365 & 0,399 \\
\hline Q46 & One department is doing the work of another & 1734 & 2,753 & 1,253 & 0,459 & 0,576 \\
\hline Q48 & Staff in new positions do not receive adequate training & 1734 & 3,035 & 1,211 & 0,439 & 0,532 \\
\hline${ }^{*} \mathrm{Q} 55$ & Sex affects changes of promotion & 1734 & 3,313 & 1,366 & 0,420 & 0,574 \\
\hline${ }^{*} \mathrm{Q} 63$ & Staff have no say in way which they are utilised & 1734 & 3,265 & 1,114 & 0,324 & 0,361 \\
\hline \#Q65 & Authority determined by position & 1734 & 2,788 & 1,101 & 0,348 & 0,383 \\
\hline * $\mathrm{Q} 67$ & Important information communicated through grapevine & 1734 & 2,776 & 1,212 & 0,417 & 0,506 \\
\hline *Q71 & Staff not consulted with regard to transfers & 1734 & 3,202 & 1,277 & 0,409 & 0,521 \\
\hline Q77 & Staff can not cope with all the changes & 1734 & 3,029 & 1,048 & 0,438 & 0,459 \\
\hline *Q80 & Written language is complicated & 1734 & 3,123 & 1,166 & 0,411 & 0,479 \\
\hline Q82 & $\begin{array}{l}\text { Different working hours of various dept. are cause } \\
\text { of dissatisfaction }\end{array}$ & 1734 & 2,978 & 1,360 & 0,453 & 0,616 \\
\hline Q89 & Managers adjust slowly to changes & 1734 & 3,099 & 1,016 & 0,451 & 0,458 \\
\hline Q95 & Senior staff take advantage of their positions & 1734 & 2,611 & 1,325 & 0,511 & 0,677 \\
\hline Q99 & Tasks expected of us, we have not been trained for & 1734 & 3,172 & 1,175 & 0,478 & 0,562 \\
\hline${ }^{*} \mathrm{Q} 103$ & There is conflict between occupational groups & 1734 & 3,343 & 1,151 & 0,506 & 0,583 \\
\hline Q108 & Work I do is below me & 1734 & 3,664 & 1,308 & 0,442 & 0,578 \\
\hline *Q110 & Some people have more power, despite position & 1734 & 2,491 & 1,214 & 0,466 & 0,565 \\
\hline Q114 & Changes are made in fast rapid succession & 1734 & 3,009 & 1,056 & 0,370 & 0,391 \\
\hline Q118 & I feel I am doing the work of somebody else & 1734 & 3,067 & 1,269 & 0,512 & 0,650 \\
\hline Q120 & Guidelines for labour relations not effective & 1734 & 3,264 & 1,013 & 0,477 & 0,483 \\
\hline Q123 & Need to economise influence efficiency & 1734 & 2,915 & 1,058 & 0,434 & 0,460 \\
\hline Q126 & We have fewer benefits than a year ago & 1734 & 3,250 & 1,236 & 0,424 & 0,524 \\
\hline *Q130 & Not clear what wishes to achieve with objectives & 1734 & 3,296 & 1,049 & 0,458 & 0,481 \\
\hline${ }^{*} \mathrm{Q} 133$ & Little opportunity to function independently & 1734 & 3,167 & 1,117 & 0,451 & 0,503 \\
\hline${ }^{*} \mathrm{Q} 137$ & Disciplinary measures not applied fairly & 1734 & 3,063 & 1,183 & 0,452 & 0,535 \\
\hline \#Q145 & There are too many changes & 1734 & 3,104 & 1,140 & 0,459 & 0,524 \\
\hline *Q146 & Each section promotes its own interests & 1734 & 2,885 & 1,107 & 0,494 & 0,547 \\
\hline
\end{tabular}

\#Items reflected

*Participation items

Cronbach Alpha $=0,843$

Total items $=30$

TABLE 8

INTERCORRELATION OF TWO SCALES

\begin{tabular}{lll}
\hline & FACTOR I & FACTOR II \\
\hline Factor I & 1,000 & \\
Factor II & 0,7452 & 1,000 \\
\hline
\end{tabular}




\section{REFERENCES}

African National Congress (1995). Herkonstruksie en Ontwikkelingsplan. Cape Town.

Allen, R.F. \& Dyer, F.J. (1990). A tool for tapping the organizational unconscious. In Bellingham, R., Cohen, B., Edwards, M. \& Allen, J. (Eds.). The corporate culture source book. Massachusetts: Human Resource Development Press.

Anstey, M. (1990). Worker Participation: Concepts and Issues. Cape Town: Juta.

Bellingham, R, Cohen, B., Edwards, M. \& Allen, J. (1990). The corporate culture source book. Massachusetts: Human Resource Development Press.

Coetzee, C. (1988). Participative management: cure for many business problems. Human Resource Management, 4 (3), 3537.

Coye, R.W. \& Belohlav, J.A. (1995). An exploratory analysis of employee participation. Group and Organization Management, 20 (1), March, 4-17.

Desatnick, R.L. (1986). Management climate surveys: a way to uncover organizations' culture Personnel, 63, (5), 49-54.

Esterhuyse, W. (1994). Jaar van oorgang - maar waarheen? Finansies en Tegniek, 46, (1), 19.

Human Science Research Council (1994). Climate and Culture questionnaire, Johannesburg.

Kaiser, H.F. (1961). A note on Guttman's lower bound for the number of common factors. British Journal of statistical Psychology, 14, (1), 1.

Kilbourne, P.J. (1991). Ondernemingskultuur: 'n dimensie van bestuur. Ongepubliseerde skripsie, RAU, Johannesburg.

Kim, J. \& Meuller, C.W. (1978). Introduction to factor analysis, what it is and how to do it. Beverly Hills: Sage.

Laubscher, J. (1991). Participative Management: Panacea or overrated concept? Human Resource Management Yearbook, 6, 32-35.

Loubser, S.S. (1988). Worker participation in the future. NAPROQ CSA, Nasionale Konvensie WNNR, Pretoria, 26-38.

Macher, K. (1991). Creating Commitment. Training and Development Journal, 45 (4), 45-52.

Madima, T. (1995). Worker participation: The elusive goal. The Black Leader, April 1995, 28-30.
Mboweni, T. (1994). The role of business in the reconstruction and development programme. Paper delivered at the 38th annual IPM-Convension, IPM, Sun City.

McLagan, P. \& Nel, C. (1995). The Age of Participatio: New Governance for the workplace and the World. Randburg, Knowledge Resources.

Miller, B. (1991). Not all it's cracked up to be? Across the Board, $28,(11), 24-28$.

Mitchell, D.E. \& Tucker, S. (1992). Leadership as a way of thinking. Feb. 1992, 30-35

Morrow, P.C., Eastman, K. \& McElroy, J.C. (1991). Concept Redundancy and rater naivety in organizational research. Journal of Applied Social Psychology, 21, (3), 219-232.

Myburg, D.J. (1990). Gereedheid van bestuur vir produktiwiteitsonderhandeling met spesifieke verwysing na werkerdeelname. Unpublished doctoral thesis, Johannesburg: RAU.

Nel, J. (1990). Value sharing a prerequisite for real transformation. Human Resource Management, 6 (3), 8-11.

Odendaal, A. (1997). Deelnemende bestuur en korporatiewe kultuur: Onafhanklike konstrukte? Ongepubliseerde M-verhandeling. RAU, Johannesburg.

Prentice, G. (1990). Adapting management style for the organisation of the future. Personnel Management, 22 (6), 58-62.

Preston, D. (1989). Personnel Management. Penquin, London.

Pretorius, B. (1995). Visionary leadership: a new era brings new demands. Human Resource Management Yearbook, 1213.

Roodt, A. (1997). In search of a South African corporate culture: Management Today. March 1997, 14-16.

Schepers, J.M. (1992). Toetskonstruksie: Teorie en Praktyk. Randse Afrikaanse Universiteit, Johannesburg.

Thomson, R. (1993). Cultural differences can enhance organisational growth. Human Resource Management, May, 4-6.

Vroom, V.H. \& Jago, A.G. (1988). The new Leadership: Managing participation in organizations. Englewood Cliffs, N J: Prentice-Hall.

Weeks, R.V. (1995). Evolving paradigms in management. Human Resource Management Yearbook, 10, 16-18.

Yukl, G.A. (1981). Leadership in organisations. Englewood Cliffs, N J: Prentice-Hall. 